\title{
$>$ \\ MYSTERY SHIPS AND RISKY "BOAT PEOPLE": \\ A DISCOURSE ANALYSIS OF NEWSPRINT MEDIA AND \\ COVERAGE OF THE 2009 TAMIL REFUGEE MIGRATION
}

by

Ashley Bradimore

B.A. (Hons), Wilfrid Laurier University, 2009

\section{A Major Research Paper}

presented to Ryerson University

In partial fulfillment of the requirements for the degree of

Master of Arts

in the Program of

Immigration and Settlement Studies

Toronto, Ontario, Canada, 2010

(C) Ashley Bradimore 2010

NOV $-\imath 2010$ 


\section{Author's Declaration}

I hereby declare that I am the sole author of this major research paper.

I authorize Ryerson University to lend this paper to other institutions or individuals for the purpose of scholarly research.

I further authorize Ryerson University to reproduce this paper by photocopying or by other means, in total or in part, at the request of other institutions or individuals for the purpose of scholarly research.

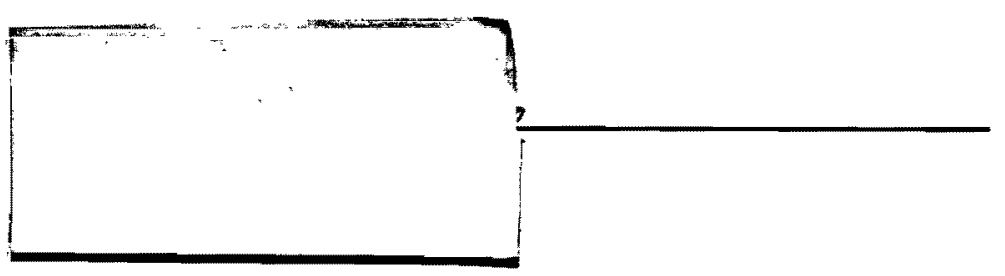




\title{
MYSTERY SHIPS AND RISKY "BOAT PEOPLE": \\ A DISCOURSE ANALYSIS OF NEWSPRINT MEDIA \\ AND COVERAGE OF THE 2009 TAMIL REFUGEE MIGRATION
}

\author{
Ashley Bradimore \\ Master of Arts, 2010 \\ Immigration and Settlement Studies \\ Ryerson University
}

\begin{abstract}
This study seeks to identify how Canadian newsprint media portrayed seventy-six Tamil refugees who arrived off the coast of Victoria, British Colombia on October 17, 2009. The corpus consists of articles published between October 2009 to January 2010 from The Vancouver Sun, The Toronto Star, and National Post. Using discourse analysis, I questioned issues of framing, representation, and identity and sought to understand how the Tamil refugee migration was understood within public dialogue. The study found that there was an overall negative representation of the Tamil refugees as the press emphasized issues of criminality and terrorism, and constructed the refugees as 'risky'. The discussion placed security - rather than human rights - as a focal point and portrayed the immigration system as both "failing" and "abused" by "bogus claimants". This security framework provided the necessary political environment for refugee reform Bill C-11 to be ushered through parliament later that spring.
\end{abstract}

Key words: Tamil, refugee, discourse analysis, risk theory, Canadian press 


\section{Acknowledgements}

Firstly I would like to thank my supervisor, Dr. Harald Bauder, who offered the support and guidance necessary to complete this paper. Dr. Bauder is dedicated to his students, working hard to provide timely feedback and constructive criticism. These efforts have been noticed by the entire ISS cohort and are greatly appreciated.

I would also like to acknowledge Dr. Vappu Tyyskä, who kindly offered her time and expertise by accepting the role of second reader. Her suggestions were a welcome addition to the final editing process.

I extend important recognition to Dr. Penelope Ironstone-Catterall, who inspired me throughout my undergraduate degree, sparked a passion for communication studies, and a particular fascination with risk theory. She unknowingly inspired not only this paper but my pursuit of a master's degree as well.

To my friends and family: thank you for sticking by me this past school year. It was only through your words of encouragement that I was able to make it through some very long days (and nights) of research and writing.

Finally, to the ISS cohort, my Ryerson family. Writing is usually a very isolating and private experience, this paper, however is the exception. We made it through the 'dark days' together and somehow came out on the other side.

\section{Dedication}

I would like to dedicate this paper to my parents and thank them both for providing an endless stream of support and encouragement throughout my studies. And to my mother in particular, who has been my teacher, my editor, my friend, and most importantly, my inspiration. 
Table of Contents

I. Introduction

Page 1-3

II. Literature Review

Page 4-13

Case study of the 1999 "boat people"

Stakeholders and Positioning

Page 6-8

Major Themes

Page 8-13

III. Theoretical Framework

Page 13-18

The Concept of Risk

IV. Methodology

Page 18-25

Discourse Analysis

Page 18-21

Researcher Positioning

Page 21-22

The Corpus

Page 22-25

V. Findings

Page 25-42

Component 1: Headline Analysis

Page 25-31

Component 2: Body Analysis

Page 32-42

The Advocate's Views

Page 43-45

VI. Conclusion

Page 45-47

VII. Newspaper Articles:

Page 48-50

VIII. Works Cited

Page 51-54 
"I can tell you now, there won't even be a quarter of them coming in...".

-Douglas Kellam, Citizenship and Immigration Canada

\section{Introduction}

On October 17, 2009, seventy-six Tamil refugees from Sri Lanka were intercepted by the Royal Canadian Mounted Police (RCMP) off the coast of British Columbia. Their migration stemmed from an eruption of violence between the Sri Lankan state and the Liberation Tigers of Tamil Elaam (the LTTE or Tamil Tigers). While the civil war had been ongoing for over two decades, the beginning of 2009 marked a particularly bloody time as the government pushed to end the conflict and defeat the LTTE. Human rights agencies and media watchdogs raised concerns over human rights violations, outraged over the displacement, internment, and death of tens of thousands of innocent civilians (Canadian Tamil Congress, 2010; Amnesty International, 2010; Human Rights Watch, 2010). These concerns were also echoed by Canadians - of Tamil ethnicity and otherwise - who took to the streets of Toronto in protest between January and May that year. Thus, one might presume that Canadians were already (semi)informed about the Sri Lankan civil war due to its visibility in the media and street protests throughout the summer (see Peter, 2009). Despite this, the seventy-six "boat migrants" did not necessarily receive a warm welcome. The Canadian media was particularly critical expressing concerns over the migrants' identity and the validity of their refugee claims; this in turn sparked debates in the media over citizenship, refugee policies, state sovereignty, and international relations.

This paper seeks to address the manner in which Canadian print media engaged with this particular refugee migration and questions both the framing and representation of the Tamils. It asks: What dominant discourses and thematic frameworks emerged to contextualize and identify the refugee? How were they understood, why were they understood in this way, and what 
conditions made these discussions possible? In this way I will seek to understand how the group was racialized, securitized, and contextualized within a discourse of risk. Only by identifying the problem - the hidden biases, misconceptions, and misrepresentations - can academia, journalists, and policy makers move forward and develop suggestions for improvements in coverage and accountability.

Using discourse analysis as developed by Van Dijk, I analyze the coverage of three Canadian daily newspapers, The Toronto Star, The Vancouver Sun and National Post. This approach offers tools in which researchers may interrogate texts and "uncover the unspoken and unstated assumptions implicit within them that have shaped the very form of the text in the first place" (Cheek, 2004: 1145). The lexicon and tone of the articles were analyzed in combination with the amount of context given; for example the background of the Tamil experience, the 'push factors' for refugees to flee, and a discussion of Canada's refugee policy and international agreements. The use and frequency of particular words were also tracked and assessed on how they influenced the overall tone of the article. This traditional method of content analysis asked what terms were used to describe the Tamils and if those terms contributed to a positive, neutral, or negative framework of understanding the Tamil refugee experience.

In congruence with the findings of previous media studies on refugee issues, I found that Canadian newsprint relied heavily on terms of illegality to describe the Tamil refugees; "bogus", "queue-jumper", "illegal", and "suspects". were typical choices which worked to establish a framework of security and risk: I conclude that this discourse of 'risky refugee' worked to legitimize the detention of the refugees for an extended period of time and also established the necessary political environment in which Federal Minister of Immigration Jason Kenney could quickly usher in Bill C-11 the following summer of 2010. This was a controversial bill which 
would overhaul Canada's refugee system and address the "bogus refugee claimants" who seemingly "abused" Canada's compassion and generosity. The 76 Tamil men, despite fleeing a well-documented violent civil war, became a focal point of Canada's flailing refugee system; it exemplified and ironically legitimized Minister Kenney's "unhappiness with the system" (Greenway, 2009, A9).

Before delving into a discussion of the Tamil migrants and the findings of Canadian media, I briefly discuss a historical example of a previous boat migration; the 1999 arrival of 599 Fujian refugees was well documented by both media and cultural analysts alike. The media furor which surrounded the event as well as the timing (having occurred almost exactly one decade prior to the Tamil refugees as well as being the last major arrival of refugee boats to reach Canadian shore) make it particularly significant to this discussion. It also offers further context for understanding the discussions which took place around the Tamils' arrival. The case study gives some insight into Canada's historical treatment of "boat people" and offers perspective on how news coverage and discourses have changed, improved, or worsened in the past decade. It urges us to critically address the contemporary security discourse which currently surrounds migration issues and leads us to ask how refugees become risky. The case study thus flows into the theoretical framework of the analyses, looking at the concept of risk theory as developed by Ulrich Beck (1986). From this position, I move into an overview of the paper's methodology, discussing the fundamentals of discourse analysis, stating my particular research position, and reviewing the corpus analyzed. This is followed by an in-depth discussion of the findings of major themes and trends. I then conclude with a final reflection on the implications of language, discourse, and the environment which successfully helped Bill C-11 pass expediently through parliament. 


\section{Literature Review}

In recent Canadian history, refugees have reached Canadian shores via boat nearly once every decade. The arrival of "boat people" happens so rarely that by the time a new boat arrives, memories of the previous boat have all but faded from societal memory. The 2009 Tamils were preceded by the 1999 refugees who fled from the Fujian province of China. Twelve years earlier, the eastern shores of Nova Scotia received 174 Sikh refugees. Just one year prior in 1986, 152 Sri Lankan Tamils reached the same coastline in August. The numbers are relatively insignificant in comparison to Canada's overall acceptance of refugees per year; in 2008, for example, approximately 36,000 people made refugee claims within Canada or at a Canadian port-of-entry; about $45 \%$ of these claims received a positive decision (Maytree, 2009). Yet despite these numbers, media spectacle has routinely surrounded each boat and heated public debate has been ignited, prompting government officials to critically review refugee policy. Before tackling the most recent media texts concerning the 2009 Tamil arrival, a discussion of the 1999 case study is valuable in exploring a historical example of the ongoing debate which has surrounded "boat people" in Canada for decades. As a literature review, it also has a practical application in reviewing academic studies and critiquing how previous discourse analyses were conducted.

The 1999 Fujian "Boat People"

Approximately 599 migrants from the Fujian province of China arrived off the coast of Vancouver in 1999. They came in four separate boats between July 20 and September 9, and if . the first arrival was met with skepticism, the last was constructed as a crisis. Public debate over state sovereignty, citizenship, and failing immigration and refugee policies erupted with the 
media, the public, and the state all voicing their concerns. The migrants' presence appeared to have exposed Canada's growing trepidation with the increasing Chinese population in Vancouver's center and suburban surroundings and immigration policies in general (Hier and Greenberg, 2002).

The event was relatively insignificant in comparison to the number of refugees accepted in Canada each year. Therefore, in comparison the 599 Chinese - although highly visible represented only a small fraction of the overall claims made. Yet the media, rather than discussing the numbers in context, framed the story within a discourse of risk allowing the migrants to symbolically represent the degrading sovereignty of the Canadian nation state. The media enflamed the situation further by racializing and criminalizing the migrants themselves. Indeed the summer of 1999 became a notable phenomenon, and interestingly, lasted long after the story faded from the media and public eye-for as the event enveloped the media, academics too became enraptured. Years later, the phenomenon remains alive through academic research, analysis, and publications. A notable number of studies have focused specifically on the event and the public dialogue which surrounded it. All media researchers concluded that the media was indeed biased, ideologically motivated, and carried racial undertones.

Researchers of the 1999 Chinese "boat people" tended to use multiple texts for analysis. All looked to English print media, the most notable being National Post, Globe and Mail, Vancouver Sun, Vancouver Province, Victoria's Times-Colonist, The Toronto Star and the Toronto Sun. Either all of these publications or a combination of some were utilized to identify commonalities, differences, and trends in reporting. The dominant time frame analyzed occurred from the arrival of the first boat on July 20 to mid October, a month after the last boat.

Unique contributions are offered by Marian Van der Zon's thesis (2000) which utilized a 
close reading of Victoria's Times-Colonist but drew examples from other sources such as Calgary Herald, Maclean's Monday Magazine, This Magazine; as well as Alison Mountz (2004) who added ethnographic research from government personnel and government documents to her reflection of content analysis, and offered a new state perspective to text analysis. Mountz and Mahtani (2001) are also unique as their scope is considerably larger covering a time frame between 1995 to1999. Their research reveals trends in media coverage of immigration issues, particularly, how an increase of interest reflects social contexts (i.e. policy development or events such as the visible Fujian migration).

Joshua Greenberg (2000) arguably led the field with his theoretically based publication, which analyzed opinion discourses or 'soft news' in six newspapers (as listed above). This study would lead to the oft quoted report by Hier and Greenberg published two years later. The second study built on Greenberg's analysis but focused on 'hard news', consciously excluding . Greenberg's previous analysis of editorials, letter's to the editor, guest columnists, etc.

\section{Stakeholders and Positioning}

Depending on the authors' position or disciplinary approach, different focal points of analysis emerged. Mahtani and Mountz's (2001) study is a government funded report, designed to improve the Province's interaction with local media outlets in immigration matters. Therefore, their purpose was not to degrade poor journalism or shed light on issues of migrant representation, but rather to present practical policy suggestions which can be adopted and implemented by both municipalities and provincial governments of British Columbia.

Clarkson (2000) offers a different reading. Coming from a journalism perspective, Clarkson focuses her analysis on issues of poor fact-checking, weak argumentation, and inaccurate reporting. Her article is succinct and effectively attacks what can only be called 'bad 
journalism'. Less methodological than Mahtani and Moutz, Clarkson discusses articles ad hoc, noting incongruent statements and rebuts with a counter argument offering 'the real picture': official statistics, supporting policy, and a wider context. She pays particular attention to articles written by Diane Francis, a columnist for the Financial Post who offers a harsh conservative and anti-immigrant stance on all issues (see also Henry and Tator 1998 for analysis on articles by Francis). The majority of studies reviewed in Clarkson's paper utilized Francis (a voice for arguments of the 'far-right') to illustrate some of the blatantly racist discussions which took place during that time period.

Clarkson offers a unique perspective by including a brief discussion of academic activism. In September of 1999, CERIS held a panel inviting academics, journalists, NGOs, and the public to discuss the media's portrayal of migrants as threat. Presumably, these types of civic engagement probably occurred across Canada in various University and organizational locations. However, they remain hidden as the remaining studies did not discuss these events. This could be because the media did not report on these public forums or researchers did not include the articles for being a 'secondary discussion' of the event. In any case, it suggests that academic activism and counter discourses are not newsworthy.

Lastly, Van der Zon (2000) approaches the issue from a dramatically different position, being theoretically grounded in studies of whiteness and critical race theory. She utilizes standpoint feminist epistemology and directly reflects upon her own subject position and how this influences her understanding and interpretation of events. Her feminist approach is indeed valuable to research on this case study. For perhaps because of her approach, she is the only one to review how gender, age, and sex, influenced certain modes of representation. Van der Zon is the sole researcher to identify that, "gender was completely lost...and the plight of individual 
women completely disappeared" from discussion (15). Likely, this information did not enter public discourse as gender destabilizes the representation of "boat people" as a mass of homogenized and de-sexed illegals. Gender is a small social identifier which some readers may identify with (also theorized by Van der Zon, 2000: 15). Furthermore, the aspect of gender could potentially undermine the security framework by inciting public sympathy for the migrants' (read: women and children) perilous journey.

\section{Major Themes in 1999 Reporting}

Despite differences in methodology every author offered substantial criticisms against Canadian English print media for producing a biased, racialized, and inequitable representation of the Fujian migrants. This bias is legitimized when one notes that whether researchers undertook a localized approach (see Mahtani and Mountz study on Victoria/surrounding area based newspapers) or a national perspective (Hier and Greenberg, 2002), they reached the same grave conclusions. Context analysis revealed that the discourse of security and risk was the dominant mode of representation utilized by the media. For all seven studies, this discourse became visible through identity terms, or what Greenberg calls "lexical selectivity". Terms such as "queue-jumper", "alien", "illegal", "human cargo", "boat people", and "detainees", depersonalized and objectified the migrants and left readers with a distorted understanding of who the migrants were and what the appropriate state response should be (Greenberg, 2000). Greenberg explains, "The general ambiguity where the migrants' identity is concerned was a central feature of the coverage and, not surprisingly has played and continues to play an integral role in the present state of refugee debates in Canada and elsewhere in the West" (523).

Most notable is the repetitive use of the term "illegal". Despite the migrants' human and 
legal rights to claim refugee status at the Canadian border, newspapers continued to identify the . migrants as "illegal" throughout the summer months (Chow-White, 2007: 11). Interestingly, then, a number of researchers noted that illegality is intertwined with the migrants' mode of transportation where "the fact that migrants arrived to Canada's shore by boat and not through 'legal channels' criminalized the migrants" immediately in the media's eye (Ibrahim, 2004: 175). This connection became visible through the media's repetitive use of images of old rusting boats in combination with news stories. The visual and textual narrative thus conflated identity with mode of transportation and forged the hyperbolic term "boat people" so heavily used throughout 1999 (Mahtani and Mountz, 2001). The association of identity with transportation existent within a discourse of illegality has had lasting repercussions, and Hier and Greenberg argue that the "ontological identity" created through "racialized imagery" suggests that any future incoming boats are "ipso facto 'illegal' and Chinese/Asian" (2002: 500).

Problematizing the terminology of newspapers is an activity undertaken by all researchers who conducted a content analysis of the 1999 Fujian migration. It is the act of 'denormalizing' seemingly neutral language. Where in research, what was once taken-for-granted unbiased talk is revealed as significantly loaded. That is how 'new racism' functions in the everyday; hiding in plain sight but perceivable to the critical eye. The importance of this can be succinctly summarized by Hier and Greenberg and thus deserves to be quoted at length:

The migrants, human beings, are subsumed under codified depersonalizing tropes and homogenized and objectified as 'things' subject to packaging, transportation and disposal... [This] racialized imagery served to accommodate 'common-sense' ideological rationalizations of migrants as 'illegals', infringing on the boundaries of the state and existing outside of the landscape of Canada's imagined community (Ibid: 501).

The racialized discourse produced within a security framework thus served as a process of Othering and legitimized any interventionist actions the state would take in the future. This 
process of racialization and securitization is observed by all studies and also reflects their theoretical applications: critical race theory and whiteness (Van der Zon, 2000), new racism (Ibrahim, 2004), standpoint feminism (Mountz, 2004), and of course critical media theory (Hier and Greenberg, 2002; Mahtani and Mountz, 2001).

Additionally, researchers have noted other negative frameworks which exist within this securitization paradigm. Firstly, an economic dimension works to both delegitimize refugee claims and identify migrants as a threat to Canadians. This argument developed from the arrival of the first boat when the media attacked migrants for not being "genuine refugees" escaping persecution, but as "economic migrants" seeking "upward socioeconomic mobility" (Greenberg, 2000: 523). As the event unfolded, the state intervened by handcuffing and containing the migrants in isolated military barracks as they waited processing. However, this housing scheme too, turned into a crisis. It had the double-barreled effect of symbolizing government incompetence while further degrading the migrants as 'burdens on the welfare state'.

Secondly, disease also became an effective tool within the security discourse. It established a 'well-founded fear' and a desire to screen and regulate the migrants' movement. Health concerns focused specifically on HIV or tuberculosis (Ibrahim, 2004) and were based on the argument that migrants would bring and spread infectious diseases. Interestingly, this argument was conflated with crime as the migrants were expected to bring and cause a rise in organized crime as well (Hier and Greenberg, 2002: 504). Nearly all researchers concluded that health concerns were either unfounded or profoundly exaggerated, and worked only to "link the threat of disease to immigration and refugee policy"' and solidify a crisis in national security (Ibid: 504).

A unique exemption is, however, important for analysis. Allan and Szafran (2005) write 
from a medical perspective and critique the state's role and effectiveness in health screening of the Fujian refugees. Their title is telling: "Health of Chinese illegal immigrants who arrived by boat on the West Coast of Canada in 1999". Their positioning within academia is explicitly visible here as they use terms such as "Chinese" and "illegal" to describe the refugees, both terms heavily criticized by social scientists. For those within cultural studies, these cultural and criminal lexicons work to homogenize, racialize, and Other the refugees' identity. The title, thus, reveals that academia outside of the humanities and social sciences may be complicit in legitimizing problematic discourses and to a lesser degree, may not be aware of the problems that such terminology pose.

While Allan and Szafran's study is not a content analysis but rather one of medial documentation, it is similar in structure as it analyzes texts and makes political recommendations thereafter based upon their 'literature review'. Their short study reviews the medical processes, diagnostics, and interactions with the migrant population and puts forth suggestions to the state for improving physical examinations of "illegal" migrants and minimizing risk in the future.

They begin their study by stating: "Immigration raises concerns regarding public health risks and increased health care costs. In the case of illegal or undocumented immigrants, the public health and cost information is generally unknown and the concerns are therefore often more intensified" (Allan and Szafran, 2005: 233). Their opening statement conflates health, risk, criminality, and economics, which articulates the security framework previously identified and critiqued by social scientists. Ironically, they counter this narrative by stating that the majority of migrants were in good health with only one case of tuberculosis diagnosed. Researchers such as Ibrahim (2004), Hier, and Greenberg (2002) were thus correct in their argument that the health 
risks were grossly exaggerated. Despite their statement, Allan and Szafran marginalize their finding by erroneously reflecting upon past research suggesting, "the overall infectious disease burden" to "likely be high" (despite their current contradictory research). For good measure, migrants are then further degraded - having disproven health concerns - through economic means. They claim: "Despite [past research suggesting disease], migrants did not show signs of significant illness and would have been actively (although illegally) employed" (236).

This medical journal manifests the same racialized discourses found within the media. It exemplifies the need for future discourse analyses to widen its scope and look beyond media texts and include academia itself as a focal point. Interestingly, medicine, science, and academia are all sites of knowledge production idealized as neutral unbiased observers. Yet despite being positioned in impartial science, Allan and Szafran (2005) cannot help but make unsubstantiated claims about the migrants' legal status. The researchers' presumption that migrants would be employed illegally assumes that their refugee claims would be denied, and furthermore, that the denied refugees would live in Canada without citizenship partaking in the underground economy. This study, though highly problematic, is important as a contributor to academic knowledge. Viewed and understood as a credible authority based in science and through the peer-reviewed journal process, this study is unique as it offers a more nuanced understanding of how discourses such as health, risk, and economics become conflated and legitimized. For Ibrahim this presentation of multiple risks works to solidify a "framework for the securitization of migration", where the layering of threats reinforces and strengthens the last (Ibrahim, 2004: 174).

At this point, it is useful to dissect this term risk, what it means for social science, and how it can impact one's interpretation and analysis of contemporary media texts. 


\section{Theoretical Framework}

The Concept of Risk

In 1986, Ulrich Beck produced the seminal text Risikogesellschaft translated to English as Risk Society (1992). His work inspired a body of knowledge concerning a change in society's relationship to technology, the environment, corporations, and government. Risk theory postulates a shift from a class society to a risk society, reflecting both changes in real conditions as well as the way hazards are conceptualized. Beck suggests that the current crisis revolves around 'the natural', encapsulating both the external environment as well as a 'crisis of culture', suffusing households, conversations, and economies (Ibid).

Beck states: "in the course of exponentially growing productive forces in the modernization process, hazards and potential threats have been unleashed to an extent previously unknown" (1992:19). This is the cultural politics of environmental risks: as nature is inescapable, the risk is potentially everywhere. This is not to state that these threats are indeed real; the crucial aspect to risk is the element of the unknown. It carries a weight of possibility, a dark glimmer of chance. Concern then, is not necessarily of the present but of what could be and it is within this expectation of risk that risk theory concerns itself.

In the introduction to The Risk Society and Beyond, Adam and van Loon explain that there is, "... a need to understand risk construction as a practice of manufacturing particular uncertainties that may have harmful consequences to life and that risks are manufactured, not only through the application of technologies, but also in the making of sense and by the technological sensibility of a potential harm, danger, or threat" (2000: 2). Analyses do not need ! to focus on whether the risk is real or constructed but rather how particular objects become construed as risky. Ergo, studies operating within the field of risk should reveal how this 
perspective becomes meaningful and shared within a society. Merit, then, lays not in the final risky object itself but in understanding the process of transformation. Researchers must ask, what symbolic actions took place to make risk possible? What conditions allowed for formerly 'safe objects' to become understood as a risky objects', furthermore feared, controlled, and managed? While traditional risk theory focuses specifically on issues of technology and environment, we may utilize this theory in a new framework and question how it may be applied to the migrant body and issues of immigration. Adeyanju and Neverson completed one study which approached this very task.

In analyzing Canadian discourse, Adeyanju and Neverson examined the media coverage of a Congolese Canadian visitor who was suspected of carrying the Ebola virus. While the majority of content analyses simply reflect on the methodological foundations of the approach, the authors took a unique approach by adopting Beck's concept of risk to interpret the data. In doing so, they argued that the case was used to create public panic by, "cross-articulating immigration and racial identity with health risks" (Adeyanju and Neverson, 2007: 79). This particular case was overdramatized in the public, where one woman came to symbolically represent the failing immigration system and became a warning of the danger in rapid 'social change'. Focusing specifically on the displacement model of risk (the idea that the concept of risk often gets displaced), Adeyanju and Neverson view the case as an example of "risk society as a 'scapegoat society"' (2007: 80; Beck, 1992: 75). The Congolese woman enraptured the media not simply because she potentially posed a health risk to Canadian citizens, but because she could visibly represent the public's growing anxiety over changing demographics and increasing racial and cultural diversity (Adeyanju and Neverson, 2007: 80).

Her body also became of particular significance through the occupation of different 
discursive spaces. The law separated her from the Canadian public through citizenship, and the media's repetitive use of 'Congolese' as an identity marker extended this space by means of Othering her culturally and racially. This outside position had a cyclical effect within the risk society: the body itself posed a potential health threat but also legitimized fears of those outside the state as diseased, infectious, and risky. It re-inscribed the panic and worked on behalf of conservative, restrictive immigration policies. The visitor's body, perceived as sickly, messy, and disordered, came to metaphorically represent a sick society: a society anxious about social change, decay, and disorder.

When reflecting upon Hier and Greenberg's (2002) study of the 'Fujian boat migrants', an interesting connection was made between health, crime, and national security. In their analysis, approximately 17 per cent of all thematic representation of the migrants demonstrated a perceived threat to national security which encapsulates public health threats as well (Hier and Greenberg, 2002: 152). A Times Colonist article from September 3, 1999 is quite illuminating in this regard, as it quotes Reform party leader Preston Manning in saying, "immigration law should ensure would-be refugees are properly screened, but if people can't get around all those provisions, then you expose yourselves to all those dangers...criminal elements and people with violent political habits and communicable diseases" (qtd. in Hier and Greenberg, 2002: 153). Manning gave an uncorroborated statement regarding the health of migrants and of the Fujian migrants in particular (as it was their arrival being addressed). More than giving the public false impressions of the migrants themselves, Hier and Greenberg note that in linking "the threat of . disease to immigration and refugee policy," Manning rationalized the "growing perception of a wider crisis in Canada's national security" (Ibid). In this way the threat of disease becomes an effective tool to enact security discourse. By inciting public panic and establishing 'well-founded 
fears', a desire to screen and regulate the migrants' movement is both created and legitimized.

In the case of the 1999 Fujian "boat people", health concerns focused specifically on HIV or tuberculosis (Ibrahim, 2004) and were based on the notion that migrants would bring and spread these infectious diseases. However, as stated earlier, researchers have since concluded that these health concerns were either unfounded or profoundly exaggerated and worked only to "link the threat of disease to immigration and refugee policy", solidifying a crisis in national security (Ibid: 504; Hier and Greenberg, 2002). In the "Securitization of Migration", Maggie Ibrahim argues that this presentation of multiple risks work to solidify a "framework for the securitization of migration", where the layering of threats reinforces and strengthens the last. Buzan et al, for example, note five major sectors in the migrant-as-threat narrative: political, military, social, environmental and economic (1998: 7). The total effect is a national crisis, so well structured and encompassing that it leaves little room for oppositional opinions (Ibrahim, 2004: 174). However, more than just the nation-state, it is important to note how this crisis comes to effect discussions in the international arena as well. Migration is not confined within the boundaries of the nation state: as we know, it is inherently a global phenomenon. Therefore, Ibrahim argues that it is vital to place and understand this idea of risk within the context of the global. The securitization of migration is not merely a Canadian phenomenon, but reflects a Western shift to a negative conceptualization of migrants and the migration process (Ibid). Migration has thus become a global risk. It embodies all spaces and all arenas; as mass exoduses can occur at anytime originating from anyplace, migration has increased in riskyness, fuelling the state's desire for increased security and management of human movement.

For risk theorists conceptualizing risk as a global phenomenon goes hand-in-hand with its very nature. Adeyunju and Neverson argue that; "the sequestration of time from space globalizes 
risks..." and moreover, are often consequences of globalization (2005: 83). They offer numerous examples of modern human made consequences, the most relevant being, “...the threat of ecological catastrophe, the collapse of global economic systems, and the rapid spread of new viruses across the world via travel" (Ibid). Interestingly, by dissecting media narratives, scholars have revealed that anti-immigrant discourses have attached each of these risks to the migrant body. Thus, despite these risks being global and generally uncontrollable, they often become personified in the immigrant experience via media spectacle.

Buzan et al. (1998: 7) state that "identifying something as a threat justifies implementing extraordinary measures to alleviate the threat. Consequently, identifying asylum seekers as a threat to some sector or element of the state calls for the implementation of measures to prevent the actualization of that threat". What has once been called "the age of migration" (Castles, 2005) has now been critiqued as the "the securitization of migration" (Ibrahim, 2004). Thus, while the movement of people may be unprecedented in terms of numbers and modes of travel, it has also become highly regulated, monitored, and controlled. A wealth of research has been published in this area, tracing the developments of the securitization and uncovering the ways immigration is linked to the phenomenon. Some researchers, such as Anastassia Tsoukala (2002; 2008), have utilized this literature as a foundation for analyzing media discourses. The age of securitized migration has spawned unique technologies of risk designed for the sole purpose of regulating human movement: interdiction, visa requirements, fences and walls, and armed border patrols have become the norm. Attacking this framework from a risk perspective allows us to reveal how such conditions become possible by problematizing and reframing public debate and state intervention not as 'normal' responses, but rather as acts of risk management. And just as theorists have noted risk societies continuous displacement of risk, so too have researchers of 
discourse analyses demonstrated that immigrants have become the stand-in for all that is risky.

O'Brien quotes an intriguing passage by Krohn, stating "those who attempt to defend questionable word choices by claiming 'it's only semantics' fail to understand that much more is involved than mere vocalization" (qtd. in O'Brien, 2003: 33; see also Krohn, 187: 147). For discourse analysts language is never neutral; in risk theory, knowledge is never innocent (Adam and van Loon, 2000: 4). The methodology and the theoretical perspective are thus exceedingly complimentary as they attack the same foundational issue of knowledge production, of possibility, and conditions. The conclusions put forth by scholars in risk and content analysis have created important contributions to the growing literature concerning immigration and risk discourses, discourses which have quietly conflated issues of health/disease, criminality, and security.

In the displacement model of risk theory, risks are so all-encompassing, so ever-present, that they get displaced within society and come to inscribe additional meanings onto unrelated objects, events, or people. It is within this movement - the act of displacing risk - that is most applicable when interpreting the empirical evidence gathered through discourse analysis; it offers a unique lens for understanding text: Together, risk theory and discourse analysis can combine and create unique and thought-provoking insights.

\section{Methodology}

Discourse Analysis as a Methodological Approach

Quantitative discourse analysis works to unearth subtle patterns of bias and racism. This approach allows one to speak not only of the obvious dominant messages but reveal the latent hidden meanings as well (i.e. that which is not said, can be equally as powerful as what is 
explicitly stated). Social theorist bell hooks has argued that modern day, "acts of blatant racism are rarely represented in mass media images" (hooks, 2002: 245). Instead 'new racism' is expressed in subtle ways such as the patterns, repetitions, positioning, and framing of stories (Ibrahim, 2004; Van Dijk, 2000). For this reason, Stuart Hall argues that critical studies and media analyses are essential in revealing today's "inferential racism" - to denaturalize the "apparently naturalized representations of events and situations of race... which have racist premises and propositions inscribed in them as a set of unquestioned assumptions" (Hall, 1981: 37). That is to say that the taken-for granted assumptions about culture, text, and talk, often reproduce the existing inequalities within society that advocates seek to break down. Language is indeed, never neutral. For Cheeks (2004: 1147), "In discourse analysis...the text is the data, and the approach is therefore not about exploring 'the' content or meaning of the text. Rather, it is about exploring how certain things come to be said or done, and what has enabled and /or constrained what can be spoken or written in a particular context".

Notable theorists of discourse analysis include Norman Fairclough and Teun A. VanDijk. Baker and McEnery reference Van Dijk in citing three fundamental questions in discourse analysis: "'How do (more) powerful groups control public discourse' and 'How does such discourse control the mind and action of (less) powerful groups, and what are the social consequences of such control, such as social inequality?"' (Baker and McEnery, 2006:198; Van Dijk, 2001: 355). In this manner, discourse analysis addresses questions of power, knowledge, social structure and inequality, through a language-based analysis. While cultural studies, as a whole, uses textual analysis to unearth social construction of gender, ethnicity, class, age, and other variances of identity, discourse analysis focuses on the role of language as a structure, producer, and regulator of these constructed cultural identities (Baker and McEnery, 2006). It 
does so by analyzing syntax, lexicon, and other linguistic structures which can divulge social meaning (lbid). There is no single method for discourse analysis and it can be used in many ways due to its multidisciplinary development (Cheeks, 2004: 1143).

One approach was developed by George Lakoff and Mark Johnson (1980) who focused their work on conceptual metaphors and linguistic deconstruction. Through their research, Lakoff and Johnson "assert that most of human's conceptual system is actually metaphorical in nature - that is language, thought, and action are all inextricably linked" (qtd. in Hardy, 2003:19). Therefore, by deconstructing common metaphorical concepts which have become normalized in everyday discourse, hidden values of a particular culture can be exposed (Ibid). Hardy's 2003 study exemplifies this. Her research on American press and Hispanic representation argues that metaphors by the press act as a sort of 'loophole' allowing the media to perpetuate negative imagery about the Hispanic community while maintaining an appearance of non-bias (Hardy, 2003; see also work by Otto Santa Ana, 1999). Her work is supported by Said's concern that "once a metaphorical statement is made and understood as fact, that statement becomes 'naturalized," is no longer understood as metaphor, and creates a "master narrative" which discourages new insights and maintains old and (perhaps unconscious) prejudices (qtd. in Hardy, 2003: 31).

Another approach to discourse analysis is Fairclough's methodology which offers tools for textual analysis which focus on metaphor, agency, nominalization and pronoun use when considering modes of production and reception texts (Fairclough, 2003). Other analysis studies use large bodies of texts and determine repetitive patterns of language and decipher the latent meanings in a larger social context (Van Dijk, 1988; Baker and McEnery, 2006). 
For Hart, “[discourse analysis] views discourse structures as linguistic representation formulated in order to achieve certain strategies" (Hart, 2007: 14). Language, then, can serve a specific function and reflect the personal motivation of speaker. As language is never neutral, referential and evaluative strategies which appear impartial can be quite provocative when considered in racist discourse. Hart asserts that referential strategies construct in-groups and outgroups through the use of categories, while evaluative strategies enact "standard arguments" such as "the topoi of danger and number of displacement", to maintain out-groups and negative attributes (Ibid).

While discourse analysis can be a valuable tool to deconstruct texts and reveal hidden ideologies and agendas, Mahtani and Mountz offer a critique. Reminding us that every theory has its failings, they state: "...results of content analysis can be over-emphasized, wherein researchers can become somewhat diverted from a focus on the social production of media content" (Mahtani and Mountz, 2001: 8). To ground the research and restrict deviation, Mahtani and Mountz stress the importance of including contextual information. The socio-historical information and the geographical and economic contexts in which these events occur are vital in understanding the conditions which make media stories possible. The context, then, can be understood as the environment or the conditions of possibility which deeply influence how stories are framed, interpreted, and managed. Thus, researchers who isolate the content may interpret the text but loose the greater meaning by ignoring the role of social production.

\section{Researcher Positioning}

In undertaking discourse analysis, it is important to reflect upon one's own positioning. I thus recognize that my life has been given a number of privileges and has developed a particular 
perspective on issues. While my class, education, and age has allowed me to develop strong media literacy, these social factors and my ethnicity also position me as an outsider to the Tamil refugee experience. Therefore, while I may have the tools to undertake the process of discourse analysis I cannot position myself or necessarily directly identify with the subject of my analysis. My knowledge and positioning grants me the ability to be critical of media discourses, challenge normalized texts, and identify problematic issues of misrepresentation and inequality.

I approach this topic with a cultural lens from a communications and global studies background and have chosen this event based on both its recent and Canadian contexts. As the event just took place, it has yet to be studied and no prior discourse analysis exists. My work will therefore expand media studies and offer something new. Upon examining my own position as a researcher within this text, I attempt to ground my analysis by utilizing the work of recognized theorists. Theory does not eliminate bias, but it may help direct and substantiate interpretations.

\section{The Corpus}

The sample focuses specifically on articles concerned with the 76 Tamil refugees and did not include articles reporting on the Sri Lankan civil war, Tamil refugees in Sri Lanka, Sri Lankan federal elections, or the Sri Lankan civil war protests which occurred earlier that summer of 2009 (see Peter, 2009 for content analysis of the later topic). One might argue that these events are all inherently connected and cannot be separated entirely. And indeed, many of these events are referenced within several of the articles analyzed. However, it is important to identify. the migrant experience so that it may not be overshadowed by the Sri Lankan state or government politics. 1 attempt to give voice, or perhaps shed light to the lack of voice given, to the 76 Tamil refugees who sought refuge on Canadian shores. 
I justify this perspective by adopting Kamala Kempadoo's argument for identifying the "transnational subaltern subject": as "certain voices have been excluded from the dominate narratives and telling of history", studies need to identify and "listen to the small voice of history" (Kempadoo, 2004: 6). This framework can be adopted in discourse analysis by focusing on migrant representation and the discussions surrounding their identity, movement, and regulation. Thus I question how the migration narrative is told, which story is dominant, and what stories are excluded. Centering the transnational subaltern subject reduces and focuses my scope, and discourages research from being swayed to issues of war and/or citizen protest.

Articles were gathered from three Canadian daily newspapers chosen for their geographical and idiomatic positions as well as circulation. The National Post is a national paper with one of the largest circulations in Canada catering to a right-wing 'highbrow' readership, the corporate elite. The Toronto Star has the largest circulation within Southern Ontario and sells to an economically and socially diverse readership. It is considered to be left-leaning. As Toronto is one of the largest recipients of immigrants and with a substantial and active Tamil community (reflected in the summer's protests), including the Toronto Star was necessary. The Vancouver Sun has the largest circulation in British Columbia and is viewed as a family or middlebrow. paper. It may offer a more localized perspective as both the journalists and the readership are directly situated within the event geographically. These papers give a combination of both national and provincial/local perspectives. Vancouver and Toronto were chosen over other cities as they are considered to be high-intake immigration cities and are close to the event via geography or Tamil community/readership.

Only hard news articles were considered. Opinion discourses such as letters to the editor and guest columnists were excluded. This decision was justified based upon the respected work 
of Hier and Greenberg, who conducted a hard news analysis of the 1999 Chinese boat migrants, excluding opinion discourses "... on the basis that they are not bound by the conventional journalistic standards of objectivity fairness and balance" (2002: 495). Hard news, conversely, “...has been subjected to the normal journalistic routines of sourcing objective data, interviewing non-partisan sources and testing for bias and validity" (Ibid). While opinion discourses are a valid text for study (see Greenberg, 2000), including these articles may open my scope too widely. I opt for hard news precisely for the reason that it is measured on standards of fairness and objectivity, and therefore it is important to highlight circumstances when this is not achieved.

The search engine Lexis/Nexis was used to find articles for the Toronto Star. The key word 'Tamil' was used to retrieve articles between October 17, 2009 to January 31, 2010. This period of analysis extends from the migrants' arrival on October 17, 2009 and when the story faded from media interest as the majority of the Tamil migrants were released from detention earlier in the year. By February, news containing key words 'Tamils' or 'Sri Lanka' retrieved articles concerned with the Sri Lankan federal election with no mention of Canada's refugee situation. The Toronto Star search collected a total of 47 articles and those not pertaining to the 76 refugees were excluded. To ensure articles were not overlooked, a secondary search was conducted using the key word "migrant" within 60 words of key word "boat". This produced 10 articles and caught a few articles the initial search had missed. Four 'soft news' such as opinion pieces or editorials were then excluded. The final Toronto Star sample contained 6 articles.

I had difficulty accessing articles for the National Post and The Vancouver Sun via Lexis/Nexis and used ProQuest via Ryerson University's Canadian Newsstand listing for each newspaper instead. The same search perimeters were used and the National Post search resulted 
in 29 articles, which was further reduced to 12 articles after an initial reading. A search for articles produced by The Vancouver Sun resulted in 23 articles and was reduced to 14 articles. The total sample for all three newspapers was 32 articles with an average word count of approximately 509. The shortest article consisted of 75 words and the longest was 1167.

\section{Findings}

Moving into a discussion concerning media and the Tamil refugees, eerie echoes of the 1999 case study emerge. While gender was not a factor in the Tamil event - as all were men themes of illegality, security, economics, and notable obsession with the migrants' boat all emerged as major topics for debate. Overall, this media study reveals an uncanny replication of the debate which captivated Canada nearly ten years ago.

\section{Component One: Headline Analysis}

The first component of analysis looks at the text within headlines, particularly the terms or descriptions used to identify the refugees. Headlines are the most prominent element of news discourse. Van Dijk (1988) has stated that headlines function as 'retrieval cues', establishing the framework in which a reader comes to understand or interpret events with certain truths (Van dijk, 1988; see also Hier and Greenberg, 2001). Ergo, a situation can be defined quite differently depending on which word is used. For example, the term "illegal" defines someone quite differently than "migrant", than "refugee", than "victim". The headline is thus deeply influential : in sending the reader signals of how to read and interpret the text, the situation, and the people involved (Van Dijk, 1988).

In all three newspapers coverage began with some skepticism of the Tamils, as little was 
known about the ship or its passengers. The first reports of the National Post and The Vancouver Sun printed headlines expressing concerns of 'human smuggling':

"Human Smuggling Suspected; 76 men aboard ship seized off Vancouver Island" (Petrescu, 2010, p. A4)

"Mystery ship suspected of human smuggling; Officials question 76 passengers as rights, Tamil groups call for compassion" (Tebrake, 2010, p. A3)

The first headlines and articles of an event are important as they can indicate a paper's starting position or first views on a particular case. The first reports published on October 19, 2009 by National Post and The Vancouver Sun categorized the migrants' arrival as a case of human smuggling. However, rather than discussing migrant welfare and contextualizing human smuggling as a human rights issue, the text positioned the event as a matter of security. Hence, we can look at how particular words worked to reframe both the event and the people involved within this discourse of security and crime. For example, using language indicative of actions which take place between criminals and police, the Tamils are "seized" and "found" within a "mysterious" environment. The relationship between the two parties is also suggestive as the Tamils are placed in a passive position in comparison to the authorities who actively capture and "question" their suspects.

This echoes Van Dijk's (1988) findings in his discourse analysis of Tamils in Dutch media. He noted that Tamils often occupied passive roles and were rarely seen as active agents. Indeed, of the 224 articles analyzed, he found that only 18 headlines focused on the Tamils themselves. Rather, the majority of headlines focused primarily on the actions of the state, and consequentially, befitted the authorities as active agents within this narrative (Van Dijk, 1988). In comparison, this study found that 17 headlines out of the total 33 articles analyzed focused primarily on the Tamils. Within these 17 headlines, 8 focused negatively on the Tamils possible 
connections to crime and/or terrorism. Some examples are: "Sri Lankan migrant wanted for smuggling; Accused of working for Tamil Tigers" (Bell, 2009, p. A1) and "A not so secret identity; Tamil boat man seeking asylum in Australia was Toronto gangster." (Bell, 2009, p. A3) from the National Post; and "Migrants' ship may be linked to people-smuggler held in Australia; Man under arrest has previous convictions" (Sinoski, 2009, p. A1) from The Vancouver Sun. Thus similar to Van Dijk's findings, Canadian press coverage of the 2009 Tamil arrival focused heavily on the actions of the state and the authorities. The few headlines which focused on the Tamil migrants themselves did so in a negative context. Thus, it is rare to find a positive description of the refugees' identities within headlines.

Placing the state authority, their responses, and interactions with the Tamil refugees at the heart of public discourse, moves the discussion away from a refugee or human rights perspective to one focused on state and security management. These patterns of placement are thus quite illuminating when considering how it can influence public dialogue, knowledge, and debate. For when migrants are discursively silenced through patterns of passive positioning, it is the state which becomes the story. This has the double-barreled effect of losing the "small voices of history" (Kempadoo, 2004: 6) while defining the Tamil refugee identity as one wrapped within and inherently tied to - the government security response system. Intertwining Tamil refugee identities with matters of security further inscribes the notion that this particular population is one that is both risky and problematic.

Despite these negative discourses, it is important to note a valuable contribution from The Vancouver Sun as it is a stand-alone paper in offering a positive tone of compassion or sympathy. In fact, it is the only paper to begin with a positive discourse and give refugee advocates a voice in the headlines. However, that said, it is significant that the 'call for 
compassion' is a secondary headline, allowing the negative component to take the lead and be most visible to readers.

The third paper analyzed, The Toronto Star, began its coverage of the Tamils' arrival with a more negative tone and included descriptive imagery of the men:

"76 illegal migrants found on ship seized off B.C.; Barefoot, bare-chested individuals on board say destination was Canada" (Fong, 2009, p. A7)

It is evident that The Toronto Star began its coverage of the event by also using a lexicon of criminality. The report identified the Tamils as 'illegal' even before full details of the men's identity and personal stories were heard or known. The descriptions of the men are noteworthy as well, as it is the only article to describe the men as "barefoot" and "bare-chested". Within this headline, the individuals described sound almost primitive and conform to an Orientalist construction (Said, 1979). For Hier and Greenberg (2001) this type of visual evidence - whether in hard photographs or descriptive language - contributes "to a reified image of the migrants as exhausted, weakened, unkempt criminals". The visual images of the migrant as criminal continued throughout the entirety of the event timeframe (noted further in analysis component two, see bottom of $\mathrm{p} 32$ for text examples).

By the subsequent week, National Post moved from a somewhat neutral position and tone to an increasingly negative tone. The following three headlines framed the refugees within a discourse of crime. While the very first report displayed concern over issues of human smuggling, the next articles voiced greater concerns for security:

"Illegal migrants paid US\$45,000 each: report; One of four ships" (Dawson, 2009, p. A2)

"Canada tipped off to ship; Foreign intelligence' tracked migrants" (Bell and Hutchinson, 2009, p. A1)

"Passenger wanted in Sri Lanka" (Bell, 2009, p. A1) 
These headlines warn of "illegal migrants" and wanted criminals; migrants risky enough to be tracked and monitored by cooperative efforts of international security intelligences. Indeed, the third headline written by Stewart Bell solidifies this discourse by identifying one refugee with an Interpol notice issued by the Sri Lankan government. The notice was based on the Sri Lankan authorities' allegations that the man had possible connections to the Tamil Tigers and supported them through an electronic smuggling ring. The allegations against this Tamil refugee had the unfortunate consequence of legitimizing the criminal descriptions of all the refugees on board based on the idea that where you find one criminal, you are likely to find another. Despite warnings from the Canadian Tamil Congress that Canada should be wary of accusations from the Sri Lankan state due to their history of false suspicions against ethnic Tamils, the press continued to focus on this man's particular case (see Bell, 2009, p. A8; Bell, 2009, p.A1; Hanson, 2009, p. A4 for examples of advocates' statements which discredit the Sri Lankan government).

The second National Post article by Bell and Hutchinson highlights two arguments commonly used against refugees. Firstly, a numbers game: the supposed ticket price of $\$ 45,000$ carries the latent suggestion that the refugee is bogus. The idea that refugees could pay such a hefty sum goes against society's conceptual understanding of who a refugee is and what they look like; the very basis of 'refugeeness' is constructed and visualized within the squalor of refugee camp, isolated, poor, and foreign. Thus, it may be inferred that headlines proclaiming a $\$ 45,000$ latently imply that the Tamil refugees are migrants in an economic capacity, merely seeking the benefits of the Canadian economy and taxpayer. In a denotative reading of the text, the headline clearly establishes an "illegal" identity for the Tamil refugees. Thus, noting that the large sum of money is paid by "illegals", the audience may read the text as further proof of their criminality. For Van Dijk (2000) the use of "numbers are the rhetorical device to suggest 
precision and objectivity, and hence credibility" (46). The numbers rhetoric operates as proof of the migrant's criminality while also legitimizing the language and discourses used in the press. In the Toronto Star's first article (Fong, 2009, p. A7), the numbers are concrete evidence of the migrant's "illegal" nature and state of being. The use of this numbers game can be noted throughout the press' coverage of the event. This will be discussed further in the second component of the analysis, which allows me to track how this argument developed and changed over time (see Inconsistencies in Reporting, p 41).

The second argument presented in Bell and Hutchinson's National Post article referred to the popular 'flood gates' rhetoric by stating that there was a pending arrival of three more ships. The 'flood gates' argument is a well-known rhetorical device which fosters public anxiety over the idea that one's country could potentially be "flooded" by "waves" of poor refugees (see Baker and McEnery 2005; Hardy, 2003; Hart, 2006; Santa Ana, 1999 and 2002). Indeed, that three more boats are moving to knock on Canada's backdoor. This headline, however, is rather misleading. The body of the article reports three ships reaching Australia's shores and there were, in fact, no ships en route to Canada as the headline passively suggests.

The Vancouver Sun - which opened with a tone of compassion - also adopted a slightly more critical perspective on the Tamil refugees. The week after the Tamils' arrival, headlines made the following proclamations:

"Migrants' ship may be linked to people-smuggler held in Australia; Man under arrest has previous convictions" (Sinoski, 2009, p.A1)

"Australia may have played role in seizure of ship" (Manthorpe, 2009, p. A9)

The press' focus on human smuggling shifted to - not the plight of the refugees themselves - but to the ship's possible criminal connections. Interestingly, the Tamils are invisible within these headlines and it is the shipping container, rather, which became the focal point of analysis and 
debate. Thus, the narrative of these texts often missed the basic question of 'Who are these people and why are they seeking refuge?' but asked 'Who owns the ship? Does it have criminal connections? And who is responsible for monitoring its movements?" The context moved from understanding the Tamils in relation to the civil war in Sri Lanka to understanding 'human smuggling' in relation to organized crime on an international stage. Sri Lanka's civil war and the root causes of the refugee exodus were muted in these headlines. Instead it is Australia - the only other Western country receiving Tamil refugees at that time - which became somewhat of a case study or focal point for the press.

The Toronto Star used a variety of terms to identify or name the migrants, the week following the Tamil's arrival:

"Migrants said to be Tamils; 76 men on merchant ship seized off coast of B.C. are asylum-seekers, Canadian Tamil group says" (Fong, 2009, p. A18)

"Agency keeps tight rein on illegal boat migrants; Lawyer refused access to group of detainees" (Fong, 2009, p. A17)

"Boat migrants' plight rekindles memories; 76 Tamils might flee if released, hearing told" (Fong, 2009, p. A12)

The second article listed here (printed October 19) can be viewed as positive in tone. It uses neutral terms such as "migrant", "Tamils" and "men", but also is the first article to identify the Tamils as "asylum-seekers". The third article (printed October 20) uses negative descriptions such as "illegal boat migrants" and "detainees", terms operating within a crime discourse. The language here is also quite loaded and reflects findings in discourse analysis of the 1999 Chinese "boat people" case study. As mentioned in the second chapter, this type of 'lexical selectively' dehumanizes the migrants and distorts public perception of who the refugees are and what the appropriate government response should be (Greenberg and Hier, 2002). 
Component Two: Body Analysis

Hierarchy of Opinion: Who gets heard?

A main point of interest within this study is in asking whose voice was heard. With Kempadoo's theory of identifying the "transnational subaltern subject" as a conceptual foundation, articles were analyzed for the ways in which different news sources were used. In this manner, I hoped to identify when the Tamil's voice or perspectives were heard, if they were able to speak for themselves, or if they were spoken on behalf of. After tracking the way sources were used, positioned, and framed, patterns quickly emerged. It became quite clear that, indeed, certain subjects are excluded from dominate narratives (Kempadoo, 2004: 6).

Looking at the National Post, for example, the dominant source consulted was government officials: authorities were the first source quoted or paraphrased and their opinions occupied the most space within the text. Within this space, multiple governmental agencies, departments, and/or officials were referenced. This gave authorities a louder voice and readers the illusion that they received the whole story created and informed by multiple perspectives. In reality, the security-driven state perspective remained the same, whether it was an unnamed government official, a spokesperson for the RCMP, or the Director of Communications. To illustrate, I take two examples from the headlines discussed in the first component of analysis.

The National Post's first article was written by Sarah Petrescu and published on October $19^{\text {th }}, 2009$. Under the headline "Human Smuggling Suspected" the following people were sourced and presented in the following order: Rob Johnston, Director of Enforcement with the : Canadian Border Services Agency (CBSA); Public Safety Minister Peter Van Loan; and David Poopalapillai, national spokesman for the Canadian Tamil Congress (CTC). The article is fairly short at 390 words and twelve paragraphs. 
Readers are first introduced to the refugees via a brief description provided by the reporter: "Two busloads of young migrant men - thought to be from Sri Lanka and possibly including boys - waved their bound hands as they left the Vancouver Island Correctional Centre..." (Petrescu, 2009, p A4). From this criminalized image of young Tamil men, the article flows into a statement given by the CBSA's director of enforcement, who speaks just outside the jail's gate. Occupying paragraphs three to five, Johnston speaks about the 'examination process' in which 'the irregular migrants' would be undergoing. The reader is then relegated with another description of the young men "whose hands were bound in plastic straps" as they were transferred from "buses with tinted windows" to ferries taking them to processing on the mainland.

Paragraphs seven and eight quoted the Public Safety Minister who is concerned with the "non-conventional fashion" in which the migrants arrived. This was followed by a brief description of how the RCMP seized and escorted the migrants' "rusty freighter" into Victoria. Advocates for the Tamil refugees were not heard until the end of the article, with Poopalapillai of the CTC sourced in paragraphs ten to twelve. The first two of these paragraphs focus on the Poopalapillai's belief that the migrants are indeed young Tamil males from Sri Lanka, who “...are the most targeted group". Perhaps the most pivotal point of his public statement - his call for the government to respect due process and humanitarian concerns - was briefly paraphrased in the very last sentence. After reading one article, this source positioning may not seem significant; it does, however develop meaning when analyzed over a period of time and is revealed as a consistent pattern of reporting. Indeed, many researchers have noted similar patterns in their respective media studies. Becker (1967) called it the 'hierarchy of credibility'. 
In his book Media, Risk, and Science, Stuart Allan explains that the standard format for hard news follows an "inverted pyramid style" where sources deemed "most newsworthy" lead and less newsworthy sources follow in descending order of significance (Allan, 2002: 111). It is an "imposed normative order" which reflects journalists' ideas about which sources are credible and which ones are not (Ibid). Unfortunately, this hierarchy of credibility has a number of consequences: it often buries oppositional views at the bottom of the narrative and thus may. influence the audience's overall reading of the event. Furthermore, it allows the primary sources to define the situation, determine which language is applicable, and what the overall tone may be (Ibid). To place this in perspective, Allan challenges this normative order by asking, what would happen if the pyramid were flipped and sources were consulted in reverse ordering? If the hierarchy began by quoting refugee advocates, would the narrative be different? How would the event be defined and what terms would be used to describe the Tamils?

Perhaps the best example of an article, defying this normative order, is the first report published by The Vancouver Sun, "Mystery Ship Suspected of Human Smuggling; Officials question 76 Passengers as Rights, Tamil Group calls for Compassion" on October $19^{\text {th }}, 2009$, on the inside spread of page A3. Out of all the articles within the corpus, it can be coded as the most positive in tone. In the following order, it quoted or paraphrased from: 'Canadian advocacy: groups'; Todd Ross, Director of Canadian Human Rights Voice; Rob Johnston of the CBSA; Public Safety Minister Peter Van Loan; David Poopalapillai of the CTC; and Todd Ross again. Ross and Poopalapillai are the two voices and perspectives from advocacy groups. Their opinions occupy paragraphs 1-2,12-23; a total of 14 out of 23 paragraphs. Thus, not only are they able to set the tone for the article but their perspective dominates the majority of the text. As secondary sources, statements from government officials had to fit into the narrative 
and follow the terminology set forth by advocates. Johnston of the CBSA and Van Loan were referenced in paragraphs $7,9,10$ and 11 respectively.

Readers of The Vancouver Sun were introduced to the migrants via the following sentence: "Canadian advocacy groups are asking the government for compassion after a boat carrying 76 people was intercepted off the coast of Vancouver Island in what officials suspect is a case of human smuggling" (Tebrake, 2009, p. A3). In contrast to the National Post's first article (Petrescu, 2009, p. A4), Tebrake's Vancouver Sun article did not offer any visual evidence - or physical descriptions - of the refugees' criminality. Rather, it used neutral terminology such as "76 people", “passengers", "people from Sri Lanka," (used by government sources) and positive terminology like "newcomers" and "asylum-seekers" (used by advocacy groups). The entire article consisted of 706 words. Within this text, the word "compassion" was used four times, "hope" five times. The event was also well contextualized with statements concerning: the Immigration and Refugee Protection Act (IRPA) which grants "refugee protection to people displaced, persecuted, or in danger" (paragraph 7), the history of Tamil migration to Canada since 1983 (paragraph 13), the refugee crisis in Sri Lanka where 280,000 people were internally displaced in refugee camps (paragraph 18), and Canada's acceptance of the 1980's Tamil "boat people" (paragraph 21).

To recount the uniqueness of the positive tone and terminology of this article, I compare it directly to an article published only two days later on October $21^{\text {st }}$. The Vancouver Sun's third article was entitled "Minister Determined to fight 'human smuggling'; Refugee Claims will be Handled as usual, he says" (Greenway, 2009, p. A9). The headline itself indicates that the article is focused on the government's perspective and in particular, the Minister of Immigration Jason 
Kenney. The Minister dominated the text, speaking with great skepticism and displeasure over the Tamil's arrival. He was either directly quoted or paraphrased:

[Kenney]...has signaled there should be no rush to unconditionally embrace as refugees the 76 men, believed to be from Sri Lanka, who arrived on the rusting boat... (paragraph 1)

"We obviously don't want to encourage people to get into rickety boats, pay thousands of dollars, cross the oceans and come to Canada illegally" (paragraph 3)

"Without prejudice to this particular group of people, all I can say is that as a country we need to make sure we are not creating a kind of perverse incentive for people to try to come to the country through these really dangerous circumstances" (paragraph 4)

[Kenney]...has long complained bogus refugee claimants are abusing Canada's system, says he plans to bring in legislation to overhaul the system before Christmas. He used the latest group of potential refugees to restate his unhappiness with the existing system (paragraphs 7 and 8)

"We want to ensure that we don't end up with a two-tier immigration system, one tier for legal law-abiding immigrants who wait patiently to come to Canada the legal way, and another that [encourages] false refugee claimants to come through the back door" (paragraph 9)

These quotes are taken from Minister Kenney's first statements regarding the Tamil's arrival. His participation in public discourse played a role in changing The Vancouver Sun's initial positive positioning. Given the spotlight within the narrative, his statements worked to discredit 'the language of compassion' set forth by advocates only two days prior. His opening statement directly counters the argument set in The Vancouver Sun's first article, urging Canadians to slow down and be more skeptical when it comes to accepting "this particular group of people". Again, in comparison to the paper's initial tone, Minister Kenney changed the terminology used to describe the Tamils and he is the first source to use the word "illegal" to define them. This illegality is further reflected in his other statements which assume the Tamils are false claimants and bogus refugees; qualifying terms such as "potential" re-inscribes this position as well.

This article relied on government officials for $100 \%$ of its sources. The narrative gave 
voice to: Immigration Minister Jason Kenney; Opposition New Democrats; Martin Collacott, former ambassador to Sri Lanka; Opposition Liberal and New Democrat MPs; Olivia Chow, NDP immigration critic; and Liberal immigration critic MP Maurizio Bevilacqua. Following the 'hierarchy of credibility', Minister Kenney was seen as a legitimate source and the most newsworthy; his comments effectively discredited advocacy groups to the extent that their voices could not be inserted within the narrative.

Changing authorship also played a major role in the change of tone within The Vancouver Sun. The initial article which carried a positive tone and focused on the perspective by refugee advocates was written by Rebecca Tebrake. This was her only article covering this event. The vast majority of articles were written by Stewart Bell, who published a total of ten articles between The Vancouver Sun and National Post respectively. Bell's articles were consistently focused on the role of the government and were extremely critical of the Tamils' refugee claims, as he reported on connections to crime, terrorism, and human smuggling.

The Spectacle of the 'Mystery Ship'

A secondary theme within the press was the spectacle which surrounded the Tamil's boat. Some articles spent their entirety discussing the possible names, origins, ownership, and cargo of the ship which carried the refugees to Victoria's coast. The following headlines exemplify this:

"Officials allege Ocean Lady was used to smuggle explosives" (Bell, 2009, p. B3)

"Ship left India last month, records show; Migrant vessel; one passenger had rebel tattoo" (Bell, 2009, p. A8)

"Tamils' ship alleged to have traces of explosives; suspected gunboat" (Bell, 2009, p. A1) 
The press actively sought to figure out the 'identity' of the boat, as if in doing so, they could pinpoint whether the Tamil passengers were 'genuine refugees' or bogus claimants and escaping terrorists. Suspicions surrounding the boat increased once it was established that the name "Ocean Lady" which was painted across the flank of the ship actually covered up an older name. For the press this was interpreted as an attempt by the crew to hide the ship's transportation history and true origins. Journalists who tried to contact the ship's operator - Sunship Maritime Services in Cebu - reached a dead end, as phone calls and emails went unanswered. The "intensive investigation into the vessel" led to reports that the ship was owned by a "ghost company" and was "identified as the Cambodian-flagged Princess Easwary" (Bell, 2009, p. A1).

To gain greater understanding about the ship, its passengers, and the event as a whole, journalists consulted 'experts' for their knowledgeable opinion. Often quoted is Rohan Gunaratna, described as a Singapore-based terrorism expert, as well as the head of the International Centre for Political Violence and Terrorism Research and author of several book on the Tamil Tigers (Bell, 2009, p. A1). He was quoted in a number of articles suggesting that the : Tamil's ship "appeared to have been a rebel vessel". This quote was followed by a fact which seemed to firmly connect the ship in question to the Tamil Tigers: "During the Sri Lankan civil war, the Tamil Tigers owned a fleet of ships that they used for smuggling weapons and supplies". (see Bell, 2009, p. A1 and Greenway, 2009, p. A9). The logic behind the argument suggests that if the ship is a rebel vessel owned by the Tamil Tigers, then one can conclude that there are Tamil Tiger terrorists on board the ship. Ipso facto, the "would-be asylum-seekers" are terrorists. Gunaratna is a source repeatedly referenced to or directly quoted in a several articles by National Post and The Vancouver Sun (see Bell, 2009, p. A1; Bell, 2009, p.A8; Bell, 2009, p. B3,). He makes multiple assertions that directly or indirectly criminalize the refugees: the ship 
was previously owned by terrorists; it has a history of criminal activity; Canada is an ideal location for the Tamil Tigers to "reconstitute"; Tamils are not in danger if returned to Sri Lanka (indeed, he states this idea is "laughable"); and the ship's captain is "a well known Tamil Tiger" involved in smuggling arms, ammunition, and explosives from North Korea to Sri Lanka. As an expert in terrorism and as a witness to the IRB hearings, his statements against the refugees carry considerable weight - which is why it is so problematic that news media fails to account for the credibility issues which have discredited several studies previously published by Gunaratna. Investigating Gunaratna publications, Peter Cronau (2003) warns the media of getting too close to their sources, finding Gunaratna to be "rarely critical of intelligence services, unless it is of the West's" (205). He states that the Professor makes "extravagant claims..without offering any evidence" (206), and in particular concern to his report on Indonesia's Terrorist Network (2002), Cronau believes Gunaratna's "writing [reveals] a remarkably narrow selection of sources, a profound lack of knowledge, and a flawed understanding, of the [country's armed forces] history" (Ibid: 205).

Indeed, Immigration and Refugee Board member Otto Nupponen was reluctant to accept Gunaratna's accusations, believing the Professor was too close to the Sri Lankan government. The Professor was born in Sri Lanka and served as an Advisor to the Sri Lankan president between 1984 and 1994 (Riegler, 2009: 7) Reflecting on Gunaratna's relationship with the Sri Lankan state, Nupponen states: "Therefore, when the good doctor says that the Princess Easwary is an LTTE ship without revealing any sources, one needs to put some thought into that. Who, in fact, are those sources? How credible and trustworthy are those unknown secret sources?" (Armstrong and Freeze, 2010, p. M1). Despite Gunaratna's credibility issues, his lack of proper sourcing, and his personal connections to the Sri Lankan government, Gunaratna 
continued to be the leading source for discrediting the Tamil refugee's claims.

The National Post's article "Passenger Wanted in Sri Lanka" (Bell, 2009, p. A1), is a good example of how connections are made between objects and people, passing criminal identities through relationships. The basic fundamental facts of this article are broken down as: one passenger is wanted for terrorism and involvement with the Tamil Tigers, all passengers arrived by a mysterious migrant ship, the Tamil Tigers are a recognized violent terrorist organization, the ship might be a rebel vessel, rebel vessels were owned by the Tamil Tigers. Tracking the connections, the argument seems almost cyclical; and the identities between the refugees, the boat, and terrorism become conflated. Moreover, the ship itself becomes a vessel for the criminal narratives: it leaks and criminalizes anyone associated with it.

Alykhan Velshi, the Federal Minister's Director of Communications and Parliamentary Affairs, reflects this sentiment by giving the following statement: "We won't allow Canada to become a place of refuge for terrorists, thugs, snakeheads and other violent foreign criminals. Nor will we support those who want to create two-tier immigration system: one tier for lawabiding immigrants who wait patiently in the queue, and a second, for-profit tier for criminals and terrorists who pay human smugglers to help them jump the queue" (my emphasis. Bell, 2009 , p. A1). Again, those who arrive by boat jump the queue and are criminals and terrorists seeking refuge in Canada. The statement unequivocally blurs the lines between who is a refugee and who is a terrorist. The findings are thus comparable to Ibrahim's conclusions for the 1999 case study: the boat comes to embody symbolic meaning of illegality and crime, which is transposed upon the passengers it carried (Ibrahim, 2004: 175). 
A number of statements were made during the first month of reporting which by the time the migrants were released, were eventually proven false. These initial facts were read as evidence of the migrants' criminality. Two major examples concern accusations against the Tamils' lack of or false identification and the supposed US $\$ 45,000$ paid for a ticket to board the ship to Canada.

Looking at The Vancouver Sun, we can see how a story changes and evolves overtime. For example, when the Tamil refugees first arrived, the press reported that the majority of the Tamils arrived without any identity documents or had illegally forged them:

"...passengers, who arrived with either fraudulent documentation or none at all" [in] "Cargo ship passenger wanted in Sri Lanka for terrorism" (Bell 23, 2009, p. A8)

As the event unfolded, this statement began to change and eventually acknowledged that indeed, some migrants had valid documentation:

"Several of the men arrived with no authentic documents to prove who they are... [migrants] without a passport or other form of ID were [detained]. Those with valid passports will have their cases heard later this week." [in] "Sri Lankan asylum-seekers plead for release from detention; Proof of identity a major hurdle as most have no authentic documents" (Hansen, 2009, p. A3)

The body of the text notes that "several" migrants appeared legitimate as they carried the proper identification, however the headline still focuses negatively as "most" migrants did not have 'authentic documents'. By the end of the corpus, the press explained this situation differently:

"Of the 76 men on board, many came with passports, but others were unable to prove who they are." [in] "Federal government invokes controversial section of law to keep migrants with ties to Tamil Tigers jailed" (Hansen, 2010, p. B1):

The last statement paints a different picture of the migrants. In the first reports, Tamils were immersed in a criminal context, as it appeared not one had arrived with the proper identity 
documents. Four months later, the press reported that in reality, the majority of migrants did come with valid passports. No retractions were made to correct this fault in reporting.

Shortly after the Tamil refugees arrived, headlines proclaimed that they had paid up to US $\$ 45,000$ for a ticket to board the ship. This was briefly discussed above where I noted how the discussion of money criminalized the Tamils and legitimized terms such as "bogus", "would-be refugee", and "false claimants".

"Illegal migrants paid US\$45,000 each: report" (Dawson, 2009, p.A2)

However, articles printed after October $20^{\text {th }}$ suggests that perhaps, the report was not accurate:

"[Vancouver lawyer Lee Rakin] said reports [migrants] had paid up to $\$ 45,000$ to come to Canada were incorrect...some had indicated they paid 45,000 Sri Lankan rupees, or about $\$ 400 \mathrm{CDN}$. Others mentioned paying in Malaysian currency." [in] "Sri Lankan migrant wanted for smuggling" (Bell, 2009, A1)

While the first headline was quick to proclaim the supposed $\$ 45,000$ fee, the correction to this report never reached headlines. Instead, it was buried 21 paragraphs down within the article. Despite the inconsistencies in numbers, Minister Kenney continued to reference the first accusations, using the numbers rhetoric to hype security concerns and the criminal connections to human smuggling.

"'We obviously don't want to encourage people to get into rickety boats, pay thousands of dollars, cross the oceans and come to Canada illegally,' Immigration Minister Jason Kenney said.." [in] "'Marathon round of hearings decides fate of men who arrived on ship" (Hansen, 2009, p. A4)

Ergo we may conclude that the initial reports published by the press are vital in influencing our understanding of the event and the people involved. Inaccurate statements or poor fact-checking can have lasting repercussions, and these are not always publically stated in newspaper retractions; nor do they reach the headlines. Rather, mistakes remain hidden in narratives that slowly change as more information becomes available. Without increasing the visibility of these 
corrections, government officials can continue to err and use false-reports to push their own agenda.

\section{The Advocate's Views}

By the last article of the corpus, newspapers reported that nearly all the migrants had been released from detention. These releases were of great reluctance to the government, whose lawyers tried to invoke the rarely used Section 86 of the Immigration Act. If passed, government lawyers and IRB tribunal members could have held secret hearings in which the last 25 refugees in detention would not be present. Instead, the refugees' interests would have been represented by a single appointed lawyer. The request for Section 86 was denied and was later criticized as a final desperate attempt by the government to keep the refugees detained. After 60 days in lockup all refugees were finally released and the majority moved to Toronto as well as other major gateway cities like Vancouver and Montreal. The story dissipated from the news soon after the new year began. Politically, however, the refugee debate continued well into the summer of 2010. It is here, within the political environment, that interesting discursive-material connections can be unveiled.

When Minister of Immigration Jason Kenney used the Tamils' arrival as an example of "a failing immigration system", it was evident that he desired a major overhaul and to implement dramatic changes to legislation which had not been altered since 2002 (see Sinoski, 2009, p. A9). Indeed, "without prejudice to this group of people", Minister Kenney seemed to make an example of the Tamil migrants: these bogus, false, criminal would-be refugees would be the last to enter Canada so easily. Bill C-11 included a number of controversial amendments to the refugee system and the first draft was strongly opposed by refugee advocate groups such as the Canadian Council for Refugees (CCR), Amnesty International Canada, and the Refugee 
Lawyers' Association of Ontario. In a joint public statement, advocates voiced their major concerns with:

"Ill-considered haste"(Canadian Council for Refugees et al, 2010): having an interview 8 days after arrival and a hearing 60 days thereafter puts many claimants at a disadvantage. It may deny refugees from retaining an appropriate lawyer, gathering enough evidence, and the ability to share narratives of violence, torture, or sexual discrimination.

"Bar on appeal for selected nationalities or groups of claimants" (Canadian Council for Refugees et al, 2010): derived from the Safe Country of Origin Clause, this bar denies some applicants - based on their nationality - equitable access to the refugee decision process. Ironically, this legitimizes a two-tiered system - the same problem the media so heavily quoted Federal Minister Kenney as being opposed to. Advocates fear this will politicize the refugee system, designating diplomatic allies and formal democracies as Safe while overlooking the human rights violations which occur in these places. For example, countries such as Mexico, Colombia and Israel are speculated to make the list, despite numerous publications by Amnesty International reporting grave human rights abuses. Furthermore, it has not been outlined who the decision maker will be and what criteria defines what is and what is not a safe country.

"Denial of humanitarian consideration and pre-removal risk assessment" (Canadian Council for Refugees et al, 2010): This amendment would deny failed claimants from seeking acceptance on humanitarian grounds, or from applying for a pre-removal risk assessment which takes into account deteriorating country conditions in which it would no longer be safe for the claimant to return. The advocates' joint statement believes this to be in violation of the Charter and international treaties such as the Convention on the Rights of the Child.

All parties concerned agreed that the system was in need of some changes: a 60,000 deep : 
backlog in claimants awaiting a decision signalled a political system in distress (Maytree, 2009). However, the changes proposed by the Conservative government sent many people into panic. Their anxiety rose further as advocates were not consulted in the initial tabling of the legislation. It was only with great advocacy and mobilization that refugee rights groups were able to have their concerns heard. Parliament eventually listened and some alterations were made, while major clauses - such as the safe third country - remained. It is likely that the spectacle which surrounded the Tamil boat arrival created the necessary environment to push Bill-C11 through parliament so quickly. The spectacle fostered a sense of anxiety around a multitude of issues like crime, terrorism, national security, and focused on the refugee system in particular. Through the anxiety driven debate, this small group of refugees came to symbolically represent the failings of Canada's too-porous immigration policies. In fact, it has become something of a trend for politicians to reform refugee policy after the arrival of "boat people".

\section{Conclusion}

In 1986 and 1987, Canada was shocked at the arrival of boats carrying Tamil and Sikh refugees respectively. A year later, government began working on new legislation to overhaul the system. On new year's day of 1989, Bill C-55 officially amended the Immigration Act which created the 'quasi' independent Immigration and Refugee Board, with the intention to reduce 'bogus' refugee claimants. The next major amendments occurred on June 28, 2002 which implemented the Immigration and Refugee Protection Act. It thus appears that in some ways, "boat people" are a catalyst for policy change. Their unexpected arrival sends waves of anxiety through public discourse and the state's response is immediately one of risk management: the boat is seized, refugees are detained, terrorism experts are consulted, policies are scrutinized and 
new legislation is drafted. This process contains the immediate risk and also attempts to minimize risks in the future. Yet throughout the process, the narrative of the refugee migrant him/herself is lost. Indeed, their rights are heard not from their own voices - but from advocacy groups who speak on their behalf. It would be naive to underestimate the importance of national security. However, it should not dominate public discourse to such an extent that those who need humanitarian compassion the most become completely dehumanized. The narrative must begin with the smallest actors, the refugees themselves, who undertook the risks of migration - only to become the risk themselves.

On August 13,2010, a second boat arrived off the coast of Victoria. Initial reports speculated that the ship is carrying almost 500 Tamil refugees, this time, with a number of : women on board as well. Their arrival comes at the end of this study and thus, at the time of writing, little was known about who the refugees were or what their claims would be. And although this is a new event, with new people and new circumstances, the dialogue has unfolded along old lines. These first reports are more critical than those written only ten months before; fears of fleeing terrorists, economic migrants, and abuses of Canada's generosity have been immediately voiced. Concerns that the passengers have "contracted highly infectious diseases such as tuberculosis" (Bell, 2010) are reminiscent of the anxieties which surrounded the 1999 "boat people". Little has changed in discourse. The state remains central to the storyline and within hours of the boats arrival, authorities explained their first actions towards risk management: the Victoria General Hospital will "absorb" sick passengers and "deploy its pandemic and disaster protocols"; the state will protect the hospital with armed security services from border services officials; and refugee policies will again be in review (Carlson and Spencer, 2010, p. A6). In fact, with the arrival of a new boat, the recent revisions of Bill C-11 do not 
appear to be enough. As Public Safety Minister Vic Toews explains: “...abuses of Canada's immigration system cannot and will not be tolerated. As we deal with this current situation under Canadian law, Canadian officials will look at all available options to strengthen our laws in order to address this unacceptable abuse of international law and Canadian generosity" (Bell, 2010).

A pattern has indeed emerged in Canada's weary acceptance of "boat people": the arrival of a mystery boat heightens anxieties, the unknown passengers are perceived as risky as the nation questions whether it is safe to welcome foreign strangers, issues of security become central to the debate and a renewed need to overhaul the immigration system is born. These mystery ships remind the body of the nation just how porous borders really are; despite tightening immigration controls, increasing visa requirements, interdicting overseas, and international intelligence agencies, some human movement escapes regulation. Refugee migration - that which is "irregular", "illegal", and undesired - will thus continue to operate outside of state boundaries. It is a movement inherently unpredictable and ergo, always risky. Without a move to change the text and talk which surrounds refugees and shift the pigeonholed focus of security to a humanitarian perspective, refugees will continue to undertake dangerous journeys simply because there is no room for them to move within the state. There cannot be humanitarian compassion when the focus is on risk management. 


\section{Newspaper Articles}

Anonymous. (2009, October 23). Canada. The Toronto Star, pp. A16.

Anonymous. (2009 December 26). Eight more migrants released from custody; Men detained when ship found off coast. The Vancouver Sun, pp. A2.

Anonymous. (2009, December 26). Eight Sri Lankan migrants set for release. National Post, pp. A2.

Anonymous. (2010, April 16). Rohan Gunaratna, Professor Terror. The Globe and Mail.

Bell, Stewart and Hutchinson, Brian. (2009, October 21). Canada tipped off to ship; 'Foreign intelligence' tracked migrants. National Post, pp. A1.

Bell, Stewart. (2009 October 22). Passenger wanted in Sri Lanka. National Post, pp. A1

Bell; Stewart. (2009 October 23). Cargo ship passenger wanted in Sri Lanka for terrorism; Subject of Interpol notice wanted for unspecified offence among 76 migrants detained after arriving off B.C. coast Saturday. The Vancouver Sun, pp. A8.

Bell, Stewart. (2009 October 23). Ship left India last month, records show; Migrant vessel; One passenger had rebel tattoo. National Post, pp. A8.

Bell, Stewart. (2009, October 26). Sri Lankan migrant wanted for smuggling; Accused of working for Tamil Tigers. National Post, pp. A1.

Bell, Stewart. (2009, November 3). Tamils' ship alleged to have traces of explosives; Suspected gunboat. National Post, pp. A1.

Bell, Stewart. (2009, November 4). Officials allege Ocean Lady was used to smuggle explosives; Immigration lawyer for Sri Lankan refugees accuses police of 'poisoning the well' with disinformation to cast the men in a negative light. The Vancouver Sun, pp. B3.

Bell, Stewart. (2009, November 10). A not so secret identity; Tamil boat man seeking asylum in Australia was Toronto gangster. National Post, pp A3.

Bell, Stewart. (2009, November 10). Deported Toronto gang member found aboard migrant smuggling ship; 'Alex' claims he's seeking asylum from persecution". The Vancouver Sun, pp B2

Bell, Stewart. (2010, August 13). Tamil ship arrives at CFB Esquimalt. National Post. 
Burgmann, Tamsyn. (2009, December 26). Tamils held in B.C. to be released, lawyer says; Would-be migrants were seized from ship this fall. The Toronto Star, pp. A7.

Carlson, Kathryn Blaze and Spencer, Christina. (2010, August 13). Authorities intercept, board migrant vessel. National Post, pp. A6.

Dawson, Fabian. (2009, October 20). Illegal migrants paid US\$45,000 each: report; One of four ships. National Post, pp. A2.

Fong, Petti. (2009, October 18). 76 illegal migrants found on ship seized off B.C.; Barefoot, bare-chested individuals on board say destination was Canada. The Toronto Star, pp. A7.

Fong, Petti. (2009, October 19). Migrants said to be Tamils; 76 men on merchant ship seized off coast of B.C. are asylum-seekers, Canadian Tamil group says. The Toronto Star, pp. A18.

Fong, Petti. (2009, October 20). Agency keeps tight rein on illegal boat migrants; Lawyer refused access to group of detainees. The Toronto Star, pp. A17.

Fong, Petti. (2009, October 21). Boat migrants' plight rekindles memories; 76 Tamils might flee if released, hearing told". The Toronto Star, pp. A12.

Greenway, Norma. (2009, October 21). Minister determined to fight 'human smuggling'; Refugee claims will be handled as usual, he says. The Vancouver Sun, pp. A9.

Hansen, Darah. (2009, October 24). Marathon round of hearing decides fate of men who arrived on ship. The Vancouver Sun, pp. A4.

Hansen, Darah. (2009, October 27). Sri Lankan asylum-seekers plead for release from detention; Proof of identity a major hurdle as most have no authentic documents. The Vancouver Sun, pp. A3.

Hansen, Darah. (2010, January 2). 28 Sri Lankan asylum-seekers ordered released; The men, who were among 76 ethnic Tamils apprehended on a rusted ship off Vancouver island, have spent more than two months in detention. The Vancouver Sun, pp.A8.

Hansen, Darah. (2010, January 7). Closed-door hearings expected for Sri Lankans; 25 migrants alleged to have Tamil Tiger ties. National Post, pp.A7.

Hansen, Darah. (2010, January 7). Federal government invokes controversial section of law to keep migrants with ties to Tamil Tigers jailed. The Vancouver Sun, pp. B1. 
Hansen, Darah. (2010, January 8). Sri Lankan detained despite release order; Government suspects man is member of Tamil Tigers, a terrorist organization. The Vancouver Sun, pp. B5.

Hansen, Darah. (2010, January 20). Government extends offers of release to 25 Sri Lankans. The Vancouver Sun, pp. A8.

Husser, Amy. (2009, December 18). Australia asks Canada to resettle Tamil refugees; Requests that unknown number be taken in. National Post, pp. A13.

Manthorpe, Jonathan. (2009, October 21). Australia may have played role in seizure of ship. The Vancouver Sun, pp. A9.

Petrescu, Sarah. (2009, October 19). Human smuggling suspected; 76 men aboard ship seized off Vancouver Island. National Post, pp. A4.

Sinoski, Kelly. (2009, October 20). Migrants' ship may be linked to people-smuggler held in Australia; Man under arrest has previous convictions. The Vancouver Sun, pp. A1.

Sinoski, Kelly. (2009, October 21). Detention hearing detains two migrants; Immigration board concerned the men who were among 76 on board rogue ship wouldn't reappear. The Vancouver Sun, pp. A9.

Tebrake, Rebecca. (2009, October 19). Mystery ship suspected of human smuggling; Officials question 76 passengers as rights, Tamil groups call for compassion. The Vancouver Sun, pp. A3. 


\section{WORK CITED}

Adam, B and van Loon, J (2000). "Introduction: Repositioning Risk; the Challenge for Social Theory" in The Risk Society and Beyond: Critical Issues for Social Theory. Ed.Barabara Adam, Ulrich Beck and Joost Van Loon. London: Sage Publication.

Adeyanju, CT and Neverson, N. (2007). "'There will be a next time': media discourse about an 'apocalyptic' vision of immigration, racial diversity, and health risks." Canadian Ethnic Studies. 39 (1-2): 79-105.

Allan, M. and Szafran, O. (2005). "Health of Chinese illegal immigrants who arrived by boat on the West cost of Canada in 1999." Journal of Immigrant Health. October 7(4): 233-238.

Amnesty International (2010). "UN Must Investigate Sri Lanka Rights Violations" Retrieved May 17 2010, from http://www.amnesty.org/en/for-media/press-releases/un-mustinvestigate-sri-lanka-rights-violations-2010-05-17.

Baker, P and McEnery, T. (2005). "A corpus-based approach to discourses of refugees and asylum seekers in UN and newspaper texts." Journal of Language and Politics 4(2): 97 226.

Beck, U. (1986). Risikogesellschaft - Auf dem Weg in eine andere Moderne. Suhrkam: Frankfurt.

(1992). Risk Society: Towards a New Modernity. London: Sage Publications.

.(2000). "Risk Society Revisited: Theory, Politics and Research Programmes" in The Risk Society and Beyond: Critical Issues for Social Theory. Ed.Barabara Adam, Ulrich Beck and Joost Van Loon. London: Sage Publication.

Buzan, B, Waever, O and de Wilde, J. (1998). Security: A New Framework for Analysis. Boulder: Lynne Reinner.

Canadian Council for Refugees, Amnesty International Canada, Canadian Council for Refugees, Refugee Lawyer's Association of Ontario (2010). "Joint Public Statement Bill C-11 Needs Thorough Review." Retrieved April 27 2010, from http://www.ccrweb.ca/en/bulletin/10/04/27.

Canadian Tamil Congress (2010). "The Case of Ocean Lady's 76 Tamil Refugees: Canadian Tamil Congress Briefing Report." Retrieved March 12, from http://www.canadiantamilcongress.ca/The $\% 20$ Case $\% 20$ of $\% 200$ cean $\% 20 \mathrm{Lady}$ 's $\% 2076 \%$ 20Tamil\%20Refugees.pdf.

Castles, S and Miller, MJ (2005). The Age of Migration: International Population Movements in the Modern World. New York: The Guilford Press. 
Clarkson, B. (2000). "600 is too many: how the press used four boatloads of Chinese migrants to create an immigration crisis." Ryerson Review of Journalism, Spring: 6-9.

Charteris-Black, J. (2006). "Britain as a container: Immigration Metaphors in the 2005 Election Campaign." Discourse Society. 17(5) 563-581.

Cheek, J. (2004). “At the margins? Discourse analysis and qualitative research.” Qualitative Health Research (14): 1140-1150.

Chilton, P. (2004). Analyzing Political Discourse. London and New York: Routledge.

Chow-White, P. (2007). "From Snakeheads to Skinheads: A Case Study on Globalization and the Local Dramastism of Race vis-à-vis Canadian News Media's Treatment of Chinese Migrants." Paper presented at the annual meeting of the International Communication Association. San Francisco, Paper. 1-26.

Cisneros, D. J. (2008). "Contaminated Communities: The Metaphor of "Immigrant as Pollutant' in Media Representations of Immigration." Rhetoric \& Public Affairs 11(4) 569-601.

Cronau, P. (2003). "The legitimizing of terror fears: Research or Psy Ops?" Pacific Journalism Review 9: 201-207.

Fairclough, N. (2000). New Labour, New Language? London: Routledge. . (2003). Analyzing Discourse: Textual Analysis for Social Research. London: Routledge.

Greenberg, J. (2000). "Opinion Discourse and Canadian newspapers: the case of the Chinese 'boat people'." Canadian journal of Communications 25(4): 517-37.

Hall, S. (1981). "The whites of their eyes: Racist ideologies and the media" in G. Dines \& J.M. Humez (Eds.), Gender, race, and class in media: A text reader (2nd ed.) (pp. 89-93). London: Sage Publications.

Hardy, V. K. (2003). "Metaphoric Myth in the Representation of Hispanics." Thesis. Georgetown University: Faculty of the Graduate School of Arts and Sciences. Washington D.C. April 16.

Hart, C. (2006). "Containers, conceptual blends and discourse space in immigration metaphors: referential and evaluative strategies." Paper presented at First International Conference, Critical Approaches to Discourse Analysis Across Disciplines. Norwich, 29-30 June. . (2007). "Critical Discourse Analysis and Metaphor: Toward a Theoretical Framework.” Critical Discourse Studies. July. 1-22. 
Henry, F and Tator, C (1998) Discourses of Domination: Racial Bias in the Canadian Englishlanguage press. University of Toronto Press.

Hier, S and Greenberg, J. (2002) "Constructing a Discursive Crisis: Risk, Problematization and Illegal Chinese in Canada." Ethnic and Racial Studies 25(3): 490-513.

Hier, S and Greenberg, J. (2002). "News Discourse and the Problematization of Chinese Migration to Canada" in Discourses of Domination: Racial Bias in the Canadian EnglishLanguage Press. University of Toronto Press.

Human Rights Watch (2010). "Sri Lanka: New Evidence of Wartime Abuses." Retrieved May 20, from http://www.hrw.org/en/news/2010/05/20/sri-lanka-new-evidence-wartimeabuses.

Ibrhaim, M. (2005). "The Securitization of Migration: A Racial Discourse." International Migration 43(5): 163-187.

Ignatow, G. (2007). Selections from: Transnational identity politics and the environment. Toronto: Lexington Books.

Kempadoo, K. "Victims and Agents of Crime: The New Crusade Against Trafficking." in Global Lockdown: Race, Gender, and the Prison-Industrial Complex, edited by Julia Sudbury, pp 35-55. 2005 Routledge.

Krohn, F. B. (1987). "Military metaphors: Semantic pollution of the market place." Et Cetera, 44: 141-145.

Lakoff, G. and Mark, J.(1980). Metaphors We Live By. Chicago: U of Chicago Press.

Levitas, R. (2000). "Discourses of Risk and Utopia" in The Risk Society and Beyond: Critical - Issues for Social Theory. Ed. Barbara Adam, Ulrich Beck, Joost VanLoon. London: Sage Publications

Mahtani, M., and Mountz, A. (2001). Immigration to British Columbia: Media Representation and Public Opinion. A paper prepared for the Ministry of Multiculturalism and Immigration, Victoria, B.C.

Maytree (2009). "Maytree: Policy in Focus" September, Issue 9. from http://maytree.com/PDF_Files/MaytreePolicyInFocusIssue9.pdf

Mountz, A. (2004). "Embodying the nation-state: Canada's response to human smuggling." Political Geography, 23: 323-345.

O'Brien, G. (2003). "Ingestible Food, Conquering Hordes, and Waste Materials: Metaphors of Immigrants and the Early Immigration Restriction Debate in the United States."Metaphor and Symbol. 18(10): 33-47. 
Riegler, T. (2009). “Terrorology': Who analyses and comments on the terrorist threat?" InterDisciplinary.net 4:1-25

Santa Ana, O. (1999). "'Like an animal I was treated': Anti-immigrant metaphor in US public discourse." Discourse and Society, 10: 191-224

. (2002). Brown tide Rising: Metaphors of Latinos in Contemporary American Public. University of Texas Press.

t'Hart, P. (2003). "Symbols, rituals and power: The lost dimensions of crisis management." Journal of Contingencies and Crisis Management. 1(1): 36-50.

Todoli, J. (2009). "Constructing Public Opinion through Metaphors" in Critical Discourse Analysis: An Interdisciplinary Perspective. Nova Science Publishers.

Van der Zon, M. (2000). "Aliens go Home: A critical Media Analysis of the Chinese Migrants." Thesis. University of Victoria, Victoria B.C.

VanDijk, T.(1988). "Semantics of a Press Panic: The Tamil 'Invasion'." European Journal of Communication. 3: 167-187

(2001). Critical discourse analysis. In: D. Schiffrin, D. Tannen and H. E.

Hamilton. (eds). The Handbook of Discourse Analysis. London: Blackwell, 352-371. 